\title{
Decolonising Western missionaries' mission theology and practice in Ghanaian church history: A Pentecostal approach
}

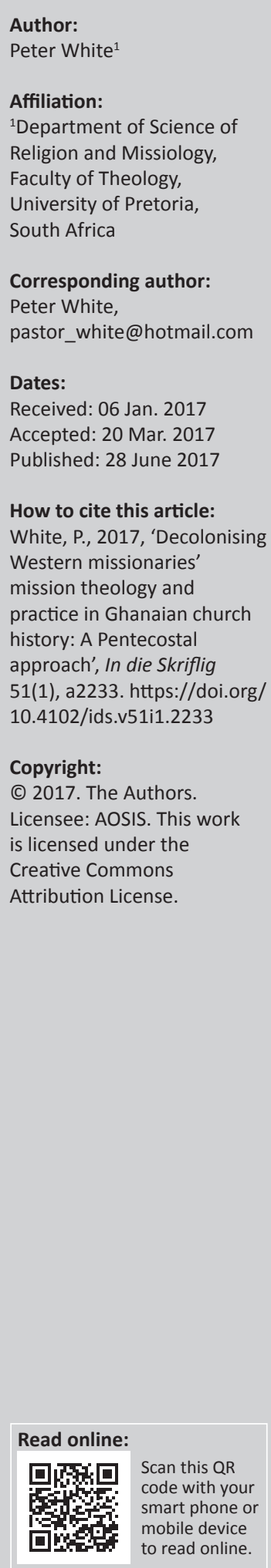

\begin{abstract}
The term missional is meant to refer fundamentally to the missio Dei, just as the term missionary does. Missiology is the systematic study of all aspects of mission. It encompasses the historical origin of the churches, their growth, successes and failures. It pays attention to the methodology and context for mission. Ghanaian church history gives us a clear picture of the massive developmental contribution the Western missionaries have made in the social, educational and economic life of Ghana. Although the Western missionaries did very well in meeting the social and economic needs of Ghanaians, they were, however, unable to make a significant and lasting impact on the religious level - mainly because they did not address the traditional worldview of Ghanaians - a worldview embedded in the belief in spirits. This therefore caused some African Christians to seek for an African identity as far as Christianity is concerned. In the light of the search for African Christian identity and mission theology, this article discusses how Pentecostalism has been used as a tool for decolonising Western missionaries' mission theology and practice in the Ghanaian context. The article discusses Pentecostalism in Ghana, Western missional theology and practices in their missionary activities in Ghana, as well as Ghanaian Pentecostals' approach to decolonisation of Western mission theology.
\end{abstract}

\section{Introduction}

The term missional is meant to refer fundamentally to the missio Dei, just as the term missionary does. The deepest, fundamental understanding of both missional and missionary verbalises the phenomenon that we understand as missio Dei (Saayman 2010:13, 15). According to Skreslet (2012:378), missiology is the systematic study of all aspects of mission. It encompasses the historical process of church growth, the historical origin of the church under investigation, its successes and failures - for the purpose of future planning and strategies. Missiology also pays attention to the methodology and context for mission (Daneel 1987:26).

Ghanaian church history gives a clear picture of the massive developmental contribution the Western missionaries have made in the social, educational and economic life of Ghana (Darkwa 2013; White 2014:1-6; Williamson 1965:152). According to Williamson (Williamson 1965:152-175), the Western missionaries did very well in meeting the social and economic needs of Ghanaians, but failed to make a significant and lasting impact on the religious level - mainly because they did not address the traditional worldview of Ghanaians, a worldview embedded in the belief in spirits.

The Western missionaries encountered the Ghanaian traditional worldview and religion from a background of Christianity embedded in the Enlightenment (Kalu 2005:228). They came with a perception and approach that presented them as superior and viewed the Ghanaian traditional worldview and culture as paganism. In the missionaries' understanding, becoming a Christian also meant becoming 'white'. This in their view implies that conversion meant totally denouncing culture. Thus the convert must learn to behave, dress and act like the missionaries. The consequence of this approach was that many Ghanaian young Christians lived a double life, i.e. had a double allegiance, which was in effect understood by the missionaries as hypocrisy. To this end, Taylor (2001:7) argues that converts of these Western missionaries were not totally submissive to Western theological worldviews. Even though the missionaries attempted to contextualise or indigenise their Western Christianity and theological orientation, but the outcomes were often too superficial.

This approach to Christian mission by the Western missionaries caused some African Christians to seek for an African identity as far as Christianity is concerned and has also encouraged African 
scholars to propound a theology of African Christianity, African theology, indigenisation of Christianity and inculturation theology (Martey 1993; Muzorewa 1985; OseiBonsu 2005; and Schineller 1990). All the above named African theologies came into African church history as a way of decolonising the Western missionaries' mission theology and approach.

In the light of the search for African Christian identity and mission theology, this article discusses how Pentecostalism has been used as a tool for decolonising Western missionaries' mission theology and practice in Ghanaian context. The article will discuss the concept of decolonisation and Pentecostalism in Ghana, Western missional theology and practices in their missionary activities in Ghana, as well as Ghanaian Pentecostals' approach to decolonisation of Western mission theology.

\section{The concept of decolonisation}

Decolonisation is the meaningful and active resistance to the forces of colonialism that perpetuates the subjugation and the exploitation of our minds, bodies, and land. Its ultimate purpose is to overturn the colonial structure and realise indigenous liberation (Waziyatawin \& Yellow Bird 2012). It engages with imperialism and colonialism at every level. This entails the corporate and national takeover of things and institutions under colonial control. This means 'writing back' against the ongoing colonialism and colonial mentalities that permeates education, media, government policies, religion and 'common sense' (Ritskes 2013).

The concept of the symbol of the sankofa in the Akan culture of Ghana, gives us an idea of Ghanaian indigenous symbolic language of decolonisation. Sankofa is an Akan 'Adinkra' symbol of a bird reaching back to retrieve the past to use it in the way forward. This is the sort of progress that is demanded by decolonisation.

Although the terms colonialism and neo-colonialism are usually discussed from a political, cultural, economic and educational perspective, it is also essential when it comes to religion and theological studies - especially in the area of missiology and Western missionaries' mission activities in Africa. The Western missionaries' activities in Africa came with a lot of Western theological orientation and colonialism in terms of their mission theology and praxis. They did not only see their theology as superior but also imposed their theological worldview on Africans converts.

\section{Overview of Pentecostalism in Ghana}

Ghanaian Pentecostals are referred to as a group of Christians who emphasise salvation in Christ as the basis for one to be filled with the Holy Spirit, and in which the 'Spirit phenomenon' (including speaking in tongues, prophecies, visions, healing and miracles in general) is perceived as in line with what happened in the Early Church in the Acts of the Apostles and accepted as a continuous experience in the contemporary church as a sign of the presence of God and experience of his Spirit (Asamoah-Gyadu 2005:12).

Long before classical Pentecostalism became formalised in Ghana, there were Pentecostal stirrings in some parts of the country, led by some indigenous prophetesses and prophets (Darkwa Amanor 2004). Pentecostalism in Ghana evolved in four phases (Omenyo 2006:5; White 2014:67-79):

- The emergence of the African prophets and charismatic personalities.

- Establishment of African Initiated Churches.

- Emergence of Classical and Neo-Pentecostal churches.

- Pentecostalisation of the mainline churches.

Historically between 1920 and 1930, a number of African Initiated Churches came onto the Ghanaian scene. The very earliest African Independent Churches (AICs) were from the tours and ministries of indigenous prophets or charismatic figures such as Prophet William Wade Harris, Prophet John Swatson, Prophet Sampson Oppong, and Apostle Peter Anim. Notable amongst these churches was the Twelve Apostles Church, the first of the AICs - led by John Nackaba and Grace Tani - which sprang up from William Wade Harris' tours through the Western region of Ghana in 1914. Other examples are the Musama Disco Christo Church, the Saviour Church, the Apostles' Revelation Society, the African Faith Tabernacle Congregation, the Eternal Sacred Order of the Cherubim and Seraphim Society, and the Church of the Lord (Omenyo 2006:73). These AICs were mainly founded by former members of mainline churches who broke away from their mother churches, and others were introduced by Nigerian migrants.

Apart from the fact that many of the AICs were founded to mainly address African Christian identity, Mwaura (2007:5) submits that some of these churches were characterised by a number of sociological, theological, political, economic and cultural as well as other factors. In Bongmba's (2003:79) view, AICs in some parts of Africa were established as a result of the general socio-political and cultural climate of discrimination, injustice, and economic marginalisation that, in turn, encouraged the search for alternative spaces in which individuals and communities could grow spiritually, socially, economically and emotionally. They exemplify the African struggle for self-identification and self-realisation. The AICs provide an avenue for African self-definition by highlighting what is good about being African and inculcating a sense of pride in that identity.

They represent a central development of Christianity in the Africa of the twentieth century (Pobee \& Ositelu II 1998:5). According to Bediako (1995:66), the AICs have pointed to the direction in which broad sections of African Christianity are moving and therefore have testified to the existence of some generalised trends in the African response to the Christian faith. They presented Christianity to the indigenes of their areas of ministry by contextualising the gospel. The main 
reason for this approach was to satisfy Ghanaian's deep religious and spiritual desires and their search for an authentic spirituality (Bediako 1995:66). The activities of the AICs have paved the way for the emergence of Classical and Neo-Pentecostalism in Ghana.

In Ghanaian Pentecostal typology, the Classical Pentecostal Churches in Ghana are the four mainline Pentecostal Churches, namely Christ Apostolic Church International, the Apostolic Church - Ghana, the Church of Pentecost and Assemblies of God. The Neo-Pentecostals are charismatic churches and the Independent Pentecostal Churches are popularly known as 'one man churches'. However, some of the Neo-Pentecostal churches are now becoming mainline churches both in nature and administrative structures (White 2015a:2). In spite of these major categories of Pentecostalism in Ghana, Ghanaian church history has also shown that Pentecostalism is not limited to Classical and Neo-Pentecostal churches in Ghana but also it has influenced church traditions of the mainline churches in Ghana (Omenyo 2006).

\section{Western missionaries' missional theology and practices}

During the colonised era the activities of the European mission churches appear to culturally colonise the spirituality and worldview of the Ghanaian. The missions undertook a campaign to transform - they used the term civilise - the African into an imitation black European. It is easy to see why the role of Christian missionaries in Africa has been assailed by many writers and social scientists as having aided and abetted colonial oppression and exploitation (Khapoya 2012:104). For instance African customs were discouraged; African languages were banned in mission schools; and African heritage was ridiculed and suppressed. The goal was to give Africans a new identity by requiring them to use new Christian names (Khapoya 2012:102). Church worship and services were celebrated in manners that appealed more to Europeans than Africans. This therefore made many African Christians feel they did not belong to the European God. Ghanaians could not worship in purely traditional attire, prayers were recited in Latin, a language they did not understand, drumming and dancing associated with an African worldview of worship was not permitted. Thus, the natives of the Gold Coast (Ghana) nicknamed Christianity 'the white man's religion'. However, within the period of 1914-1937 some Africans began to find expression for the kind of Christianity contextualised in the African way of worship and spirituality.

Western missionaries' missional praxis in Ghana was socially and economically centred. They saw mission as the provision of Western education, introduction of international trade and agriculture (White 2015b:3-5). They approached discipleship in Ghana through a system of Christian communal settlements at their mission stations called 'Salem concept'. Though these settlements helped in the physical character formation, believers who settled in the Salem communities lacked proper biblical discipleship and spiritual maturity.

\section{Contextualisation of theology: Ghanaian Pentecostals' approach to decolonisation of Western mission theology}

According to Pobee (1991:985), every theology is contextual and there is no neutral theology. This implies that all theologies are embedded in worldviews that shape the way we see things (Tiénou \& Hiebert 2005:122). According to Walls (1997:45) our experiences and relationships influence the development of our theological perceptions. Each Christian theologian has a template and this template operates distinctly. It is this template that helps theologians to interpret, correlate, and access things in relation to their faith and in a particular context. The process of contextualisation of theology in this regard becomes necessary when people become dissatisfied with the existing tradition or when they have realised that the existing tradition is not addressing their issues or concerns (White 2012:8). They therefore reflect on their situations in the light of Scripture in order to find the best solution that can address their issues. In carrying out these reflections, theologians are influenced by the context of their experiences, culture, tradition, social or geographical location and social changes (Bevans 2004:5-6; Wilson 1997:1-6). It should be noted at this point that, in order for theology to remain relevant, it must address issues in their own local context (Beyers 2016:6).

Analysis of both the Old and New Testament show a picture of contextualisation at various places and seasons. God related to people in the Bible in various contexts and these contexts influenced the content of how they understood God and related to Him. In a similar way, in the African's quest to understand and relate to God in their context, they contextualised their form of theology, viz. African theology (White 2012:2). In the context of African Christianity, Pentecostalism gained popularity and was accepted by many Ghanaian Christians because it addresses their pneumatological worldview. It therefore became one of the tools for the decolonisation of the Western missionaries' mission theology and praxis. Details are discussed in the subsequent subheadings.

\section{The role of African charismatic figures}

One of the major contexts for the decolonisation of the Western missionaries' missional praxis in Ghana was the emergence of indigenous charismatic figures such as Prophet William Wade Harris, Prophet John Swatson, and Prophet Sampson Oppong. These charismatic personalities emerged in Ghanaian church history between 1920 and 1930.

These personalities exhibited revivalist tendencies and emphasised faith healing, fasting, and exorcism of evil spirits. They made the gospel relevant to the indigenes. They offered a unique opportunity for observing how the black people, once they have been removed from the immediate influence of Western missionaries, deal with the Christian religion in their 
own way (Daneel 1987:26). They understood Sub-Saharan African situations and confronted them with confidence and assurances from relevant Scriptures in the Bible.

Thus they connected the Christian message with the spiritual needs of Ghanaians by demonstrating that God cares about those needs and makes provision for his people by helping to meet them. They presented a solution for a turning away from traditional resources of supernatural support to seek refuge in the Almighty God (Asamoah-Gyadu 2005:40).

The role and ministries of these indigenous charismatic or prophetic figures gave birth to several disciples and some of their disciples moved out of the then mainline churches to plant churches that emphasises Pentecostal doctrines and practices. Their ministries also made the Western missionary theology redundant in the light of the worldview of indigenous Christians. They demonstrated the power of the Holy Spirit in their preaching, healing and deliverance activities.

\section{Emphasis on the Holy Spirit}

The theological reflection of early Pentecostals on church mission started with the conviction that the New Testament church was called into existence and empowered for evangelistic witness throughout the world (Dempster 1999:48-49). The tenet of the Church of Pentecost states that 'it is therefore expected of the Spirit filled believer to bear the fruit of the Holy Spirit, since the Holy Spirit is living in them and also helping them to live a 'Christlike life and actively participate in the missio Dei' (CoP 2014a). In this context it is required that their followers are filled with the Holy Spirit and the subsequent manifestation of the gifts of the Holy Spirit (White 2015a:3).

The doctrinal position of the Church of Pentecost (2014b) states that:
All believers in Christ Jesus are entitled to receive, and should earnestly seek, the Baptism of the Holy Spirit and fire according to the command of our Lord Jesus Christ. This is a normal experience of the Early Church. With this experience comes power to preach and bestowment of the gifts of the Holy Spirit. The believer is filled with the Holy Spirit; there is a physical sign of 'speaking in other tongues' as the Spirit of God gives utterance. This is accompanied by a burning desire and a supernatural power to witness to others about God's salvation power. (pp. 19-21)

According to Newbigin (1978:63-66), mission is not just something which the church does; it is something which is done by the Holy Spirit who is Himself the witness, changing both the world and the church, Who always goes before the church in her missionary journey. This implies that it is therefore by the action of the sovereign Spirit of God that the church is launched on its mission.

In Ghanaian Pentecostal understanding, it is impossible to be engaged in mission without the Holy Spirit. Pentecostals place primary emphasis on being 'sent by the Spirit', and depend more on what is described as 'the Spirit's leading' than on formal structures (Anderson 2005:31). The pneumatological dimension of Pentecostal understanding of Christianity has to do mainly with the spiritual freedom to incarnate the gospel anew into the diverse cultures that exist: to believe in the power of the Holy Spirit is to believe that God can and wants to speak to people today through cultural mediation. Being Pentecostal would mean to affirm such spiritual freedom (Dempster1999:133-134).

\section{Emphasis on the discipleship}

Discipleship is one of the core components of Christian mission. Mission is replicated discipleship, learned through ethical obedience and passed on through teaching (Mt 28:18 20; Bosch 1991:56; Wright 2006:391). Christianity without discipleship is Christianity without Christ (Bonhoeffer 1995:59). The ultimate purpose of discipleship is to help believers to be nurtured spiritually and develop a Christlike character - a life of strict adherence and obedience to Christ and his commandments. It is also a strict adherence to Christ as the object of our faith (ibid:54, 87, 93).

Unlike the way in which Western missionaries approached the discipleship of indigenous Ghanaian Christians which was carried out through 'the salem system of settlement' at their mission stations, the Pentecostals approached discipleship in an inclusive manner. Salem was a kind of community established by the Basel missionaries (Presbyterian missionaries) for indigenous Christians. Under this system of discipleship, converts were required to move out of their traditional homes and settle in 'Christian quarters' or 'salems' on the outskirts of the community (Kpobi 2008:76).

Even though the missionaries had good reasons for what they did, it eventually resulted in the separation of Christian converts from their kith and kin, thus creating a cleavage in the community. This approach to discipleship seriously harmed the communal life of the affected communities. It also undermined the authority of traditional rulers and family elders. Apart from this, the converts were not only separated from their families but were not properly discipled through the teaching of the word of God (White 2015b:4).

In addressing this challenge of separating the converts from their communities and relations, Pentecostals approached their discipleship in the context of the church through Sunday school and home cells. The home cells did not only benefited the converts but also created room and opportunities for other non-Christians and relations in the vicinity to hear the gospel and also to be discipled. This fundamental approach to mission and discipleship has helped the Classical Pentecostal Churches in Ghana to avoid the clericalism and nominal spirituality associated with the Christianity of the older mission denominations (Asamoah-Gyadu 2013:16).

Ghanaian Pentecostals' discipleship meetings are often characterised by the study of the Word of God and people are 
allowed to ask questions that borders on their faith and spirituality.

\section{Missional inclusivity}

Unlike the Western missionaries' exclusive mission approach, Ghanaian Pentecostals approach mission in an inclusive manner. This is achieved through the emphasis on ministry of all believers. In their understanding, every believer is gifted and anointed to participate in the missio Dei according to their gifts and talents. Pentecostals' view of missional inclusivity says that God is an extra-ordinary God Who uses ordinary believers who avails themselves to Him for extraordinary activities.

To put emphasis on this view, the Apostolic Church of Ghana (2013) states that:

As a movement, we are passionate about seeing individual lives connected with Christ and being empowered by the Holy Spirit, equipped to fulfil their God-given purpose and released into mission for the glory of God. As each local Apostolic Church stays committed to equipping and releasing, there will be no end to the number of lives that will be built and the number of communities that will be transformed in Ghana and beyond

Articles seven and eight of the 16 fundamental truths of the Assemblies of God - Ghana (2013) also says:

We believe that all believers are entitled to and should ardently expect and earnestly seek the promise of the Father, the baptism in The Holy Spirit and fire, according to the command of our Lord Jesus Christ. This was the normal experience of all in the early Christian Church. With it comes the endowment of power for life and service, the bestowment of the gifts and their uses in the work of the ministry.

Pentecostal view of mission is that every gift and talent is given to individuals in the church by God for missional purposes (White 2015b:5-6). The ultimate purpose of God's blessing of believers with spiritual gifts is for ministry within the church, mission to the world, and church growth. This approach breaks the protocol between the laity and clergy when it comes to issues related to mission. This is what Asamoah-Gyadu (2005:27) termed as 'democratisation of ministry'. Pentecostals in this regard see mission as a call to every believer.

\section{Self-finance approach}

Pocock et al. (2005:279) are of the view that money is a twoedged sword, for it can either empower or hinder missionary efforts. They are of the view that often there is a conflict of interest between the funding and the receiving agents. Their argument proposes a self-support approach to mission.

Unlike the Western missionaries understanding of mission as supplying indigenous Ghanaian Christian financial support for their mission activities, the early Classical Pentecostals detached themselves from this mindset of dependence on external support with the exception of the Assemblies of God - Ghana which was founded and supported by American missionaries.
Self-finance therefore became one of the ways Classical Ghanaian Pentecostal churches have decolonised the Western missionaries' concept of financing mission.

The Church of Pentecost (2013) presents the following view on their mission funding:

The Church of Pentecost operates from the basic financial philosophy of 'self-support'. This is based on the covenant between the Church's founding fathers and God which states, inter alia, that the Church of Pentecost should not borrow money from outside the Church for the funding of her evangelistic programmes. It does not, however, refuse unsolicited financial support from philanthropists for some of her social services. The two principal financial sources of the Church are tithes and offerings. As and when necessary, special funds are raised at all levels of the Church's administrative structure to meet very crucial financial commitments. The prudent management of the self-financing policy has been able to sustain the Church even in a developing country like Ghana.

In Koduah's (2004:110) view, one of the factors that served as a catalyst for the phenomenal growth of the Church of Pentecost was its 'financial self-supporting policy'. Some of the sources for funding mission for many of the classical Pentecostal churches are the following:

- Fund raising for mission - weekly, monthly.

- Tithes and offerings.

- Individual donations.

- Income from investments, schools and business - for example rentals of conference rooms, church premises, and church buses.

These approaches for missional self-financing are not only seen in the Church of Pentecost but also the Christ Apostolic Church International and the Apostolic Church - Ghana.

\section{Decolonising the gospel and culture}

Though gospel and culture was always moving on a parallel line, the missionaries were antagonistic to the idea of a marriage between the gospel and the various cultures they encountered.

The issue at stake here is similar to the one faced by the Early Church both in Jerusalem as well as with Paul and his colleagues who were carrying the gospel from Jerusalem to Antioch (Ac 6:1-7; Ac 10-15, Gal 3:26-28). In their case, the issue most fundamentally had to do with the relationship between the Christian community and Judaism, especially in the matter of temple worship and law. In all these challenges the church leadership did their best to resolve the issue of gospel and culture, with the best example of this being the Jerusalem council meeting (described in Ac 15) on the issue of circumcision.

In order to address the problem of gospel and culture, the importance of the contextualisation of the gospel became a view shared by many theologians and was strongly pushed by the Ecumenical Association of Third World Theologians 
(EATWOT). Out of this came terms such as adaptation, accommodation, indigenisation, incarnation, contextualisation, and inculturation.

Though none of these approaches is perfect, the idea behind each of them is to present the gospel to suit the worldview and culture of people, communities and nations without compromising the essence of the gospel (Bosch 1991:420-432).

One of the approaches that have been strongly pushed in Ghana is inculturation. This term is commonly used to refer to the adaptation of the way church teaching is presented to non-Christian cultures, and to the influence of those cultures on the evolution of these teachings (Osei-Bonsu 2005:1-5, 20). Sarpong (2002:9-10) argues that by inculturation the evangeliser seeks to present the gospel to the people of different religio-cultural contexts in such a way that they are not alienated from their own cultures, but find their cultures enriched and fulfilled through the gospel. Niemandt (2013:2) posits that in regard to the generally agreed-upon understanding that the mission of the church is the mission of God working amongst people, the Christian church needs to understand and respect the context of their surrounding as they present the gospel. Furthermore, based on the view that the Bible by its very nature is contextual, inculturation should be an integral part of our understanding of communicating the gospel, if the gospel is indeed to be truly communicated (Bevans \& Schroeder 2011:9).

A study of the ministries of the precursors of Ghanaian Pentecostalism such as William Wade Harris, John Swatson, Sampson Oppong, and Apostle Peter Newman Anim attest to the fact that their mission and ministries depicted an integration of gospel and culture. This was demonstrated in their worship style and expression of spirituality that addresses issues of demonic activity, poverty, disease and death as well as salvation of the soul (White 2014:83-86). They took the African ethos seriously, initiating a shift from the reductionism associated with the then traditional Western missionary churches in which peoples' religious experiences were seen as either superstition or as figments of imagination, and provided solutions to deal with the worldview of Africans.

According to Meyer (1999:216), the popularity of Pentecostalism in many parts of Africa may be due to their understanding that it deals with the Spirit-world. Vanden Toren (2013:7-8) argues that the Western missionaries overlooked the role of the traditional African worldview in their approach of presenting the gospel to Africans. They saw these traditional worldviews on spirituality as merely superstition and thus did not help to find adequate alternative solutions to them. The consequence of this approach led young Christians to live a double life, understood by the missionaries as hypocrisy.

Pentecostals in response to the negative attitude of the Western missionary towards the worldview of the indigenes, approached their mission praxis by integrating African culture into their singing, drumming and dancing as they praise and worship God.

\section{Joyous celebration and noise}

Black Africans are noted to be people of singing, drumming and dancing. A lot of African music and songs deal with religious ideas and practices. Music gives them an outlet for their emotional expression and religious life. Contrary to this vibrant way of expression of black Africa, the Western missionaries' liturgy of hymns did not make room for many black Africans who became Christians to really express their joyous worship according to their worldview.

Pentecostalism came in to decolonise this concept of worship through vibrant worship, praise, dancing, drumming and the making of noise in the Holy Spirit. MacRobert (1992:4-5, 79) posits that Pentecostalism has largely been coloured by a distinctively black culture, thus producing a black form of Christianity and this is many times seen in their vibrant approach to worship and joyous celebration.

The tendency of the Ghanaian Christian to be inclined towards noisy worship emanates from the fact that noise is primarily part of the Ghanaian (many black Africans) and for that matter, the African worship life. The phenomenon of religious noise was prevalent in African society even before the advent of the various Western religions (Kyei \& Kuwornu-Adjaottor 2016:33). One of the unique features of Pentecostalism is the very expressive, expectant, dynamic, exuberant, experiential, and interventionist nature of its worship.

\section{Conclusion}

The ministry of Western missionaries in Ghana has made a great impact in the developmental, educational and economic life of Ghana. However, the same cannot be said of their impact on the spiritual needs of Ghanaians. The article noted that European mission churches in Ghana during the colonial era appeared to culturally colonise the spirituality and worldview of the Ghanaian. This was achieved by demonising African customs, banning African languages in mission schools as well as ridiculing and suppressing African heritage. Their goal was to give Africans a new identity. This article, in response to this challenge, made a case for how Pentecostalism was used to close the gap in the spiritual needs of Ghanaian Christians of the then mainline churches, as well as being used to decolonise the Western missionaries' mission theology and praxis.

The article further discusses the emergence of African charismatic figures, their emphasis on the Holy Spirit and discipleship, missional inclusivity, self-finance of mission activities, contextualisation of the gospel and culture, as well as the joyous celebration of God in their worship as some of the approaches used by Ghanaian Pentecostal churches in decolonising the Western missionaries' mission theology and praxis. 


\section{Acknowledgements Competing interests}

The author declares that he has no financial or personal relationships which may have inappropriately influenced him in writing this article.

\section{References}

Anderson, A., 2005, 'Towards a pentecostal missiology', Asian Journal of Pentecostal Studies 8(1), 31

Apostolic Church - Ghana, 2013, 'Rules of believes', viewed 12 August 2013, from http://www.theapostolicchurch.org.gh/content/worthy-mention

Asamoah-Gyadu, J.K., 2005, African charismatics: Current development within independent indigenous Pentecostalism in Ghana, Brill, Leiden.

Asamoah-Gyadu, J.K., 2013, 'The promise is for you and your children: Pentecostal spirituality, mission and discipleship in Africa', in M. Wonsuk \& J.K. Ross (eds.), p. 16, Regnum Books International, Oxford. (Regnum Edinburgh Centenary Series, vol. 14).

Assemblies of God - Ghana, 2013, Articles 7 and 8 of the sixteen fundamental truth of the Assemblies of God Ghana, viewed 12 August 2013, from http://www.agghana. $\mathrm{org} / \mathrm{hq} / \mathrm{gh} /$ index.php/about-us/7-agghana/about-us/21-fundamental-truth

Bediako, K., 1995, Christianity in Africa: The renewal of a non-Western religion, Orbis Books, Maryknoll.

Bevans, S.B., 2004, Models of contextual theology, Rev. \& exp. edn., Orbis Books, Maryknoll.

Bevans, S.B. \& Schroeder, R.P., 2001, Prophetic dialogue: Reflections on Christian mission today, Orbis Books, Maryknoll.

Beyers, J., 2016, 'Theology and higher education: The place of a Faculty of Theology at a South African university', HTS Teologiese Studies/Theological Studies 72(4), a3450, https://doi.org/10.4102/hts.v72i4.3450

Bongmba, E.K., 2003, 'Christian reform movements', in P.T. Zeleza \& D. Eyoh (eds.), Encyclopaedia of twentieth-century African history, pp. 77-83, Routledge, London.

Bonhoeffer, D., 1995, The cost of discipleship, Simon \& Schuster, New York.

Bosch, D.J., 1991, Transforming mission: Paradigm shifts in theology of mission, Orbis Books, Maryknoll.

Church of Pentecost, 2013, Church Government, viewed 13 December 2013, from http://www.thecophq.org/index.php/the-church/church-government

Church of Pentecost, 2014a, Core values, viewed 8 October 2016, from http://www. thecophq.org/pages.php?linkID=2\&linkObj=cat

Church of Pentecost, 2014b, Home cell study guide, Pentecost Press, Dansoman.

CoP, see Church of Pentecost

Daneel, M., 1987, Quest for belonging, Mambo Press, Harare.

Darkwa Amanor, J., 2004, 'Pentecostalism in Ghana: An African reformation', Cyber Journal for Pentecostal-Charismatic Research, viewed 4 October, 2016, from http://www.pctii.org/cyberj/cyberj13/amanor.htm

Dempster, M., 1999, 'A theology of the kingdom: A pentecostal contribution', in V. Samuel \& C. Sugden (eds.), Mission as transformation: A theology of the whole gospel, Regnum Books, Oxford.

Kalu, O.U. (ed.), 2005, African Christianity: An African story, University of Pretoria, Pretoria.

Khapoya, B.V., 2012, The African experience: An introduction, 4th edn., Routledge, Abingdon.

Kodua, A., 2004, 'The Church of Pentecost in a postmodern society', in O. Onyinah (ed.), p. 110, Pentecost Press, Accra. (James McKeown Lectures).

Kpobi, D.N.A., 2008, Mission in Ghana: Ecumenical heritage, Asempa Publishers, Accra.

Kyei, S. \& Kuwornu-Adjaottor, J.E.T., 2016, 'Noisy or joyfully noisy: A study of Christian church services in Kumasi, American Journal of Arts and Humanities, 1, A25-A36, viewed 13 November 2016, from http://www.ASRAresearch.org/ajah-vol-1no-1-2016/

MacRobert, I., 1992, 'The black root of Pentecostalism' in A.B. Jan \& A.O. Jongenee (eds.), Pentecost, mission and ecumenism: Essays on intercultural theology, pp. 4-5, 79, Peter Lang, Frankfurt.
Martey, E., 1993, African theology: Inculturation and liberation, Orbis Books, Maryknoll.

Meyer, B., 1999, Translating the devil: Religion and modernity among the ewes in Ghana, Edinburgh University Press, Edinburgh.

Muzorewa, G.H., 1995, The origins and development of African theology, Orbis Books, Maryknoll.

Mwaura, P.N., 2007, 'Alternative vision for transforming development: Perspectives from Christianity with particular reference to new Christian expressions in Africa', Paper presented at Transforming Development Conference, 15-17 October 2007 Soesterberg, Netherlands.

Newbigin, L., 1978, The open secret, Eerdmans, Grand Rapids.

Niemandt, C.J.P., 2013, Artisanal cheese or artisanal Jesus, Paper presented at creative and critical dialogue on the future of Missiology as a theological discipline, Unisa, Pretoria.

Omenyo, C.N., 2006, Pentecost outside Pentecostalism, Boekencentrum, Zoetermeer.

Osei-Bonsu, J., 2005, The inculturation of Christianity in Africa: Antecedence and guidelines from the New Testament and the Early Church, Peter Lang, Frankfurt.

Pobee, J.S., 1991, 'Contextual theology', in Dictionary of the Ecumenical Movement, p. 985, World Council of Churches, Geneva.

Pobee, J.S. \& Ositelu II, G., 1998, African initiatives in Christianity, World Council of Churches, Geneva.

Pocock, M., Gailyn van Rheenen, G. \& McConnell, D., 2005, The changing face of missions, Baker Academics, Grand Rapids.

Ritskes, E., 2012, What is decolonization and why does it matter?, viewed 17 October 2016, from https://intercontinentalcry.org/what-is-decolonization-and-why-doesit-matter/

Saayman, W., 2010, 'Missionary or missional? A study in terminology', Missionalia 38(1), 13, 15.

Sarpong, P.K., 2002, People differ: An approach to inculturation in evangelism, SubSahara Publishers, Accra.

Schineller, P.S.J., 1990, A handbook on inculturation, Paulist Press, New York.

Sepúlveda, J., 1999, 'Indigenous Pentecostalism and the Chilean experience', in Pentecostals after a century: Global perspectives on a movement in transition, A. Anderson \& W.J. Hollenweger (eds.), pp. 133-134, Sheffield Academic Press, Sheffield.

Skreslet, S.H., 2012, Comprehending mission: The questions, methods, themes, problems, and prospects of missiology, Kindle version, Orbis Books, Maryknoll.

Taylor, J.V., 2001, Christian presence amid African religion, Acton Publishers, Nairobi.

Tiénou, T. \& Hiebert, P.G., 2005, 'From systematic and biblical to missional theology', in C.H. Kraft (ed.), Appropriate Christianity, pp. 117-134, William Carey, Pasadena.

Vanden Toren, B., 2013, 'Teaching ethics in the face of African moral crisis: Reflection from a gust', Transformation: An International Journal of Holistic Mission Studies 30(1), 7-8

Walls, A., 1997, The missionary movement in Christian history: Studies in the transmission of faith, Orbis Books, New York.

Waziyatawin \& Yellow Bird, M., 2012, For indigenous minds only: A decolonization handbook, School of American Research Press, Santa Fe.

White, P., 2012, 'A cry for freedom: The African women's quest in the light of the Bible', American Journal of Biblical Theology 13(52), 1-28.

White, P., 2014, 'Missiological study of the role of the baptism and infilling of the Holy Spirit in Ghanaian pentecostal churches, PhD thesis, Department of Science of Religion \& Missiology, Faculty of Theology, University of Pretoria.

White, P., 2015a, 'Religion, mission and national development: A contextual interpretation of Jeremiah 29:4-7 in the light of the activities of the Basel Mission Society in Ghana (1828-1918) and its missiological implications', Verbum et Ecclesia 36(1), Art. \#1419, 6 pages, https://doi.org/10.4102/ve.v36i1.1419

White, P., 2015b, 'A missional study of Ghanaian pentecostal churches' leadership and leadership formation', HTS Teologiese Studies/Theological Studies 71(3), Art. \#2865, 8 pages, https://doi.org/10.4102/hts.v71i3.2865

White, P., \& Niemandt, C.J.P., 2015, 'The missional role of the Holy Spirit: Ghanaian pentecostals' view and practice', In die Skriflig 49(1), Art. \#1987, 7 pages, https:// doi.org/10.4102/ids.v49i1.1987

Williamson, S.G., 1965, Akan religion and the Christian faith, K. Dickson (ed.), Ghana University Press, Accra.

Wilson, R.F., 1997, 'Contextual theology and global Baptist', in D. Carro \& R.F. Wilson (eds.), Contemporary gospel accents: Doing theology in Africa, Asia, Southeast Asia and Latin America, p. 1-6, Mercer University Press, Macon.

Wright, C.J.H., 2006, The mission of God: Unlocking the Bible's grand narrative, InterVarsity, Downers Grove. 